\title{
The krushchkevka and the dom kultura: urban lifestyles in a rural setting
}

\author{
Oksana Zhukova ${ }^{1},{ }^{1}$, and Simon Bell ${ }^{1}$ \\ ${ }^{1}$ Estonian University of Life Sciences, Chair of landscape architecture, Tartu, Estonia.
}

\begin{abstract}
Collectivisation in the Soviet Union, including the Baltic States, involved many aspects related to living conditions and architecture. One of the dominant images of village centres in Estonia and Latvia is that of the standardised urban forms of blocks of flats and other buildings such as schools and administrative buildings. On collectivisation, new village centres arose, promising "Urban lifestyles in a rural setting". There are very few designs for blocks of flats - standardisation came in with Krushchev and the first generation of flats built of white brick became known as Krushchevki. Alongside these were buildings to serve as places where the new Soviet cultural activities could take place - the Dom Kultura which, in contrast to the standard flats, was often of a special one-off design. These can often be found to be abandoned and derelict nowadays, since they have no function and represented the Soviet regime. The objective of this study was to examine the plans and initial proposals for several kolkhoz centres and, using computer aideddesign, to recreate 3D models of the building ensemble as it was originally planned, to compare this to what was actually built and to what remains now and the extent to which they are still used. We found that while the standard flats were built according to plan, external landscape features were often omitted. The unique designs of the culture houses often contained many interesting Modernist or even post-modernist features but changed during construction and were often built of poor materials and finishes. They were vandalised, robbed of materials and are now abandoned in many cases. Their architects often went on to make a post-Soviet career and there is considerable interest in their designs. They represent a lost legacy of the period.
\end{abstract}

\section{Introduction}

Collectivisation in the Soviet Union, including the Baltic States, involved many aspects related to living conditions and architecture. One of the dominant images of village centres in Estonia and Latvia is that of the standardised urban forms of blocks of flats and other buildings such as schools and administrative buildings with a very modern appearance. On collectivisation, new village centres arose, promising "urban lifestyles in a rural setting". Up to that point the country people - farmers mainly - lived in wooden farmhouses scattered across the landscape, mainly located in convenient locations on

\footnotetext{
${ }^{1}$ Corresponding author: oksana.zhukova@emu.ee
} 
their land as opposed to the concentrated villages typical of Russia, for example. This distribution was almost certainly itself a reform of farming patterns undertaken by the German landowners in the 19th century and developed somewhat further during the land reforms of the first independence period between the First and Second World Wars when the estates were broken up [1: 19].

\section{Rural settlements pre-collectivisation}

In relation to rural settlement patterns in Latvia, a study in the 1980s [2] showed that there were originally a number of distinct traditional regional settlement types which became altered as a result of the Soviet changes. The same is broadly true of Estonia.

\section{Collectivisation and the need for rural housing}

While collectivisation of agriculture has its roots in the 1920s and was enforced with tremendous brutality, for example in Ukraine in the 1930s, it came later to the Baltic States as they were only incorporated into the Soviet Union in 1945. As a result of the war the rural population declined and also much housing stock was lost, especially where intense fighting had taken place, since wooden houses burn easily [3].

In addition to the depredations of the war there was a mass deportation plan for 30,000 people in Estonia and over 40,000 from Latvia to Siberia in March 1949 under Operatsya Priboi ("operation coastal surf") which emptied many parts of villages and houses. Over 8,000 people managed to escape, but 20,722 (7,500 families, over $2.5 \%$ of the Estonian population, half of them women, over 6,000 children under the age of 16 , and 4,300 men) were sent to Siberia during the three days of the operation. Slightly more than $10 \%$ were men of working age. The deported included disabled people, pregnant women, babies and children separated from their parents. Portrayed as a "dekulakization" campaign, the operation was intended to facilitate the forced collectivisation and to eliminate the support base for the armed resistance of the Forest Brothers against the Soviet occupation. The deportation fulfilled its purposes: by the end of $1949,93 \%$ of the farms were collectivized in Latvia and $91.6 \%$ in Estonia by the end of 1950 [4].

The process of change to settlements from the traditional patterns noted above was broadly that, during the 1950 s, farming activities were moved to the centres of the newly established kolkhoz and sovkhoz [5]. This process was intensified after the "Resolution of 1961" on the displacement of inhabitants to villages and multi-storied blocks of flats and manufacturing units. Urban building types such as blocks of flats began to appear. The construction of central villages and the elimination of individual farmsteads continued until the 1980s $[6,7,8]$.

The situation therefore was that the rural population was much reduced in number, the need for agricultural workers great, the residential housing stock in poor condition and the dispersed housing pattern was not very amenable to social control. Moreover, with the approach to collectivisation came industrialisation of agriculture and centralisation of production organisation, management and control. In part, in order to attract workers to the agricultural sector it was necessary to build new housing complexes which were centrally located for the kolkhoz or sovkhoz functioning and also to permit much more political and social control over the population. This development coincided with the "thaw" period under Krushchev and also the development of industrialised housing construction $[9,10]$. 
As part of the development of the kolkhoz and sovkhoz there was also a need for administrative and representative buildings - such as the central administration. The dom kultura or "house of culture" was an especially important edifice built to host the many social and collective activities that took place to propagandise the residents and to instil a sense of collective identity with the new state, to raise the new generations as good Soviet citizens and to hold cultural events [11]. This offered a rare opportunity for local architects to experiment with designs (see below).

\section{The origins of housing planning in the Soviet Union}

Already in the 1930s and 1940s there was a severe shortage of housing in the Soviet Union in part as a result of urbanisation and industrialisation. Many people lived crammed together in communal apartments (kommunalki). After the Second World War, there was the added factor of widespread devastation of the areas invaded by Germany and destroyed by shelling or bombing. Thus, the need arose for a huge mass housing programme which was to be fast, cost effective and functional in architectural and fabrication terms. The khrushchevka (хрущёвка) was the result of this development, originally planned and designed for urban areas, and the term is an unofficial name for the low-cost, white silicate brick or concrete-panelled three- to fivestoried apartment building which was developed during the early 1960s, during the time that its namesake Nikita Khrushchev was First Secretary of the USSR. The apartment buildings also went by the slang name of Khruschoba (Хрущёв+трущоба, Khrushchev-slum).

The development of the prototypes took place in Moscow between 1954 and1961, supervised by a team led by engineer Vitaly Lagutenko, who became chief planner of Moscow in 1956 [12]. The team designed and tested the mass-scale, industrialized construction process, based around the developing technology of concrete panel plants and a quick assembly schedule. In 1961, Lagutenko's institute presented the K-7 design for a prefabricated 5-story building (without a lift) that became typical of the khrushchevka. 64,000 units of this type were built in Moscow alone from 1961 to 1968. Khrushchevkas featured combined bathrooms which had been introduced in the prizewinning Bolshaya Kaluzhskaya building designed by Ivan Zholtovsky. Lagutenko continued the space-saving idea, replacing regular-sized bathtubs with $120 \mathrm{~cm}$ long "sitting baths". This feature - a flat with an indoor bathroom with running water and flush toilets - was actually to be a real attraction of the otherwise cramped flats, especially for rural people who had never seen such things! The flats were also centrally heated using a district heating system.

By the middle of the Soviet period in the Baltic States (late 1960s / early 1970s) collectivisation had sufficiently advanced to enable the use of a limited variety of Krushchevki of both white brick and panel construction, with some smaller versions (fewer flats) and different panel models (with or without balconies, different finishes and fenestration) appearing over time but essentially with the same internal layout. Kolkhoz centres then became identifiable and dominated by these buildings. In later years some individual houses also appeared - there was a standard form used in Latvia known as the Lìvāni-type, for example.

Khrushchevka standard types were classified into "disposable", with a planned 25year life (сносимые серии) and "permanent" (несносимые серии). This clearly has implications for rural housing policies since all the disposable versions (especially the cheaper panel varieties) are long past their original lifespan - although renovation, addition of insulation and new roofs etc. has been undertaken in some places where 
the residents can afford this. There has also been substantial modification by the residents such as enclosing balconies and other features which change the appearance from the original.

\section{The role of individual architecture and architects}

Since the housing (and most agricultural buildings and production facilities) were constructed to the standard forms, the role of bespoke architecture tended to be limited to special buildings such as culture houses, some schools and kindergartens and occasionally hotels or other special structures - especially if the kolkhoz was well off. These made use of the talents of local architects who only had the possibility to develop and apply their design ideas under such conditions, sponsored by the state. When these buildings were designed and constructed in the late 1970s or 1980s there had been considerable debate about the direction of Estonian architecture in the Estonian SSR and an exhibition to look at this held in 1978 in Tallinn considered the direction of Modernism an in the Estonian context and what building forms might be adopted [13]. The result in part at least was that some new approaches emerged and fresh directions going into the 1980s up to the collapse of the system. Modernism and later some dabbling with what is recognisably post-modernism emerged in forms of buildings designed by these architects. These led to a wide range of distinctive buildings which can still be found all over the Baltic landscape in a way not found elsewhere in the former Soviet Union [14].

\section{Research aims and objectives}

Within the MODSCAPES project one theme is the study of the legacies of the era under investigation - both of the landscape and the built heritage. Owing to the fact that since the collapse of the kolkhoz system and the restitution of private property as well as the redundancy of many agricultural and productive structures with no function or economic value, the current landscape in its structure and appearance (and for the purpose of this paper the built ensemble of the kolkhoz centres) is potentially rather different from its original form. In order to examine and communicate the originally-designed and built characteristics of a kolkhoz centre to current generations it is not sufficient to show plans, drawings and photographs - the three-dimensional spatial aspects are important; and with the advent of video and computer-generated 3D imagery a much more communicative version of the original set of buildings is possible. This can also help in interpretation of the evolution and modification of the standard or bespoke designs from drawing board to implementation as well as to explore the spatial arrangements of the residential and other buildings.

The objective of this study was therefore to examine the plans and initial proposals for several kolkhoz centres and, using computer aided-design, to recreate 3D models of the building ensemble as it was originally planned, to compare this to what was actually built and to what remains now and the extent to which they are still used.

\section{Methods}

We based our work on several examples within the Estonian and Latvian case studies within the MODSCAPES project. We constructed 3D computer models of the buildings which formed part of the original kolkhoz ensemble and then compared these to what 
was constructed and how the places look today. In this short paper, owing to lack of space, we present two such examples.

The first project, Omedu, is a specially designed factory and office complex built to produce fake or ersatz caviar in eastern Estonia, a remote outstation of the once successful fishing kolkhoz of Kirov (located at Viimsi near Tallinn) now completely derelict, abandoned and overgrown. The complex, designed by Ado Eigi (1938-2008) who was the chief architect at the Kirov kolkhoz, was constructed in the late 1980s and contains a number of clear references to Nordic post-modernism then in vogue [15] (Fig. 1). As it was constructed towards the end of the Soviet period when the economy was in serious decline the building materials were of low quality. The complex is now in ruins, having been stripped of anything useful and additionally, the winter frosts have affected the brick and concrete, spalling it severely.
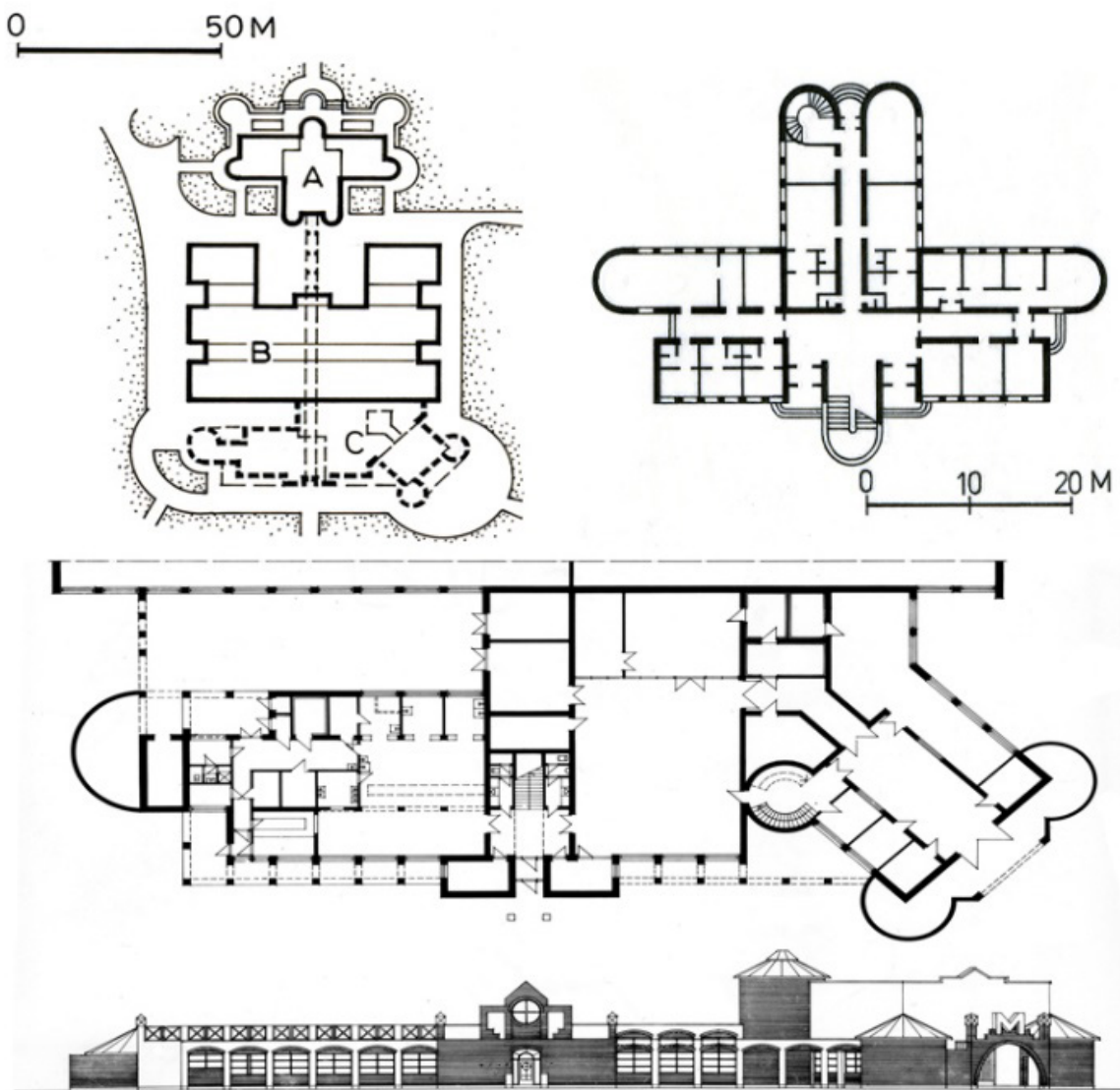

Fig. 1. Plans and elevation of the original Omedu design by Ado Eigi (Reproduced from the architect's archives by permission of the son of the architect)

The second location, Laeva, was a sovhoz with a role in agricultural research and has a typical complex of krushchevki of both brick and panel construction together with some other buildings such as a school/kindergarten, shop and club and a very unique dom kultura. This culture house was built in 1980 to a design by Toomas Rein (1940-) and is now in ruins [16]. 


\section{Modelling procedure}

To create the 3D models, we carried out the following steps:

1. We took available materials concerning the designs for the bespoke buildings such as design drawings, photographs taken when they were newly constructed and we supplemented this by some measurements on site to check dimensions and location colours and textures of materials (if colour photos were unavailable).

2. For the krushchevki we relied on location maps, on-site measurements and photographs for the main dimensions and locations together with information such as photos from other sources showing the same model types in their original form. We were able to consult maps from the time of construction for the footprints, although the scale was not always such that an accurate outline could be obtained.

3. Using the computer programme ArchiCAD we constructed 3D models of each of the buildings reflecting as accurately as we could the original completed form or rather the originally planned completed form.

4. The models of the buildings were then assembled onto a base layer constructed to include level changes and the original road layout, tree plantings etc. as far as could be found out.

5. Once the models were constructed we were able to create visualisations based on viewpoints to match photographs - original historical photos from archival sources and contemporary photos taken from as close to the original viewpoints as possible.

\section{Results}

\section{Omedu}

We found that in Omedu the building sat within a much more open setting than is currently the case, with the facades of the complex clear and readable with post-modern details at the entrances, for example. There had been substantial modification to certain sections as the design moved to construction - some elements were removed and others added, such as a whole section with an imposing doorway was never constructed.

The design featured a combination of red brick with white infill panels and special glassed-in staircases and a connecting passage which linked the offices with the factory and warehouse areas. There was also a pump house and a generator plant and a culture house which was only partly constructed and never finished. The residential buildings were much more traditional and contrasted strongly with the main complex.

Owing to the ruinous state of all buildings (expect the residential houses still occupied), as well as the encroachment of the vegetation it is almost impossible to understand and appreciate how the complex must have first appeared, for example to a visitor. The models show how dramatic the complex was originally and give a much better feeling than is possible from the surviving photographs. 

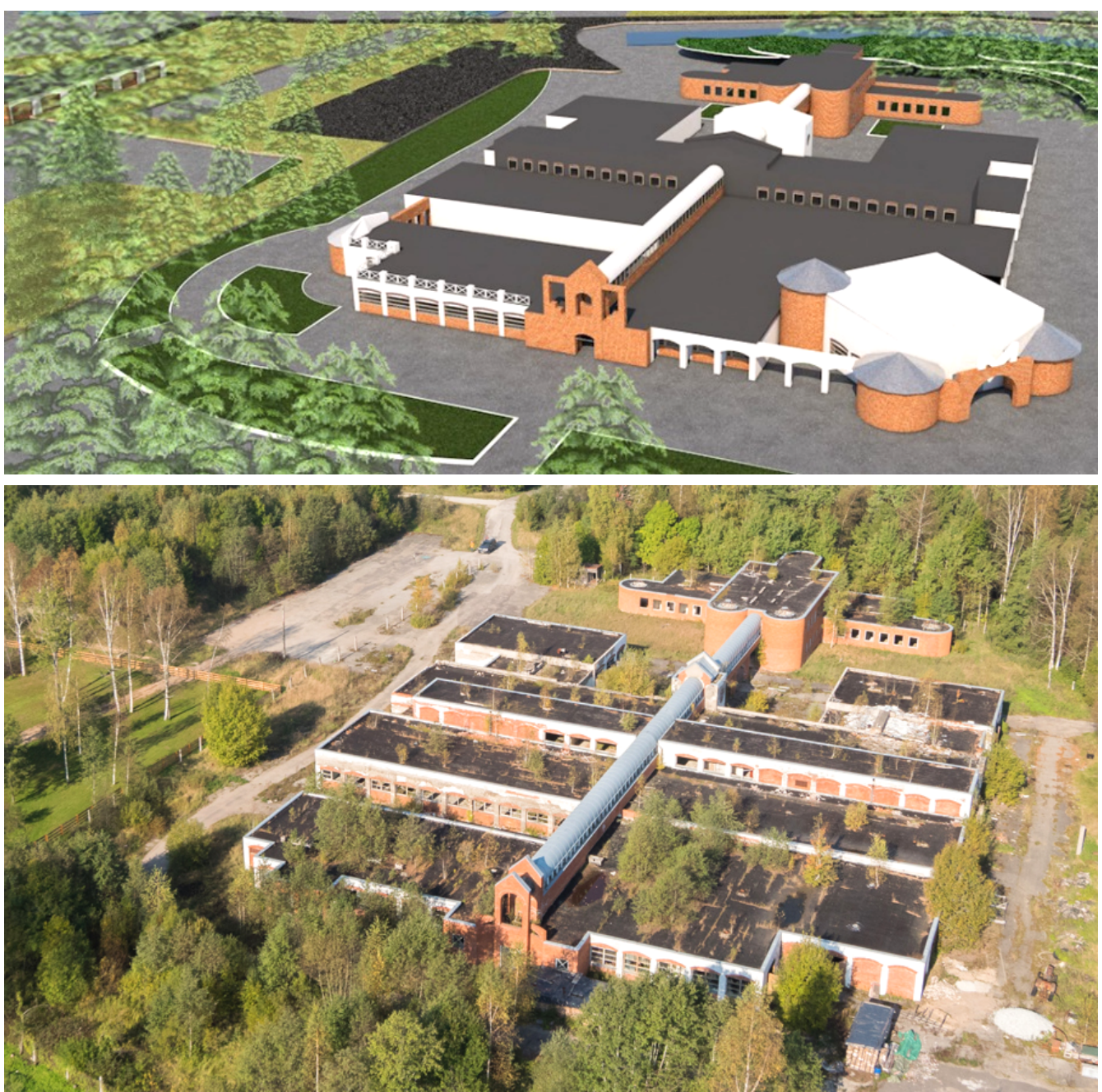

Figs. 2a, b. An aerial view of the complex as it would have been if completed according to the plans (a) lying in an open setting, and (b) as it was in 2013, showing how the forest has encroached and trees have even started to grow on the roofs. (Sources: a) Kaiti Lillepuu, CC BY-SA 3.0 b) Oksana Zhukova) 

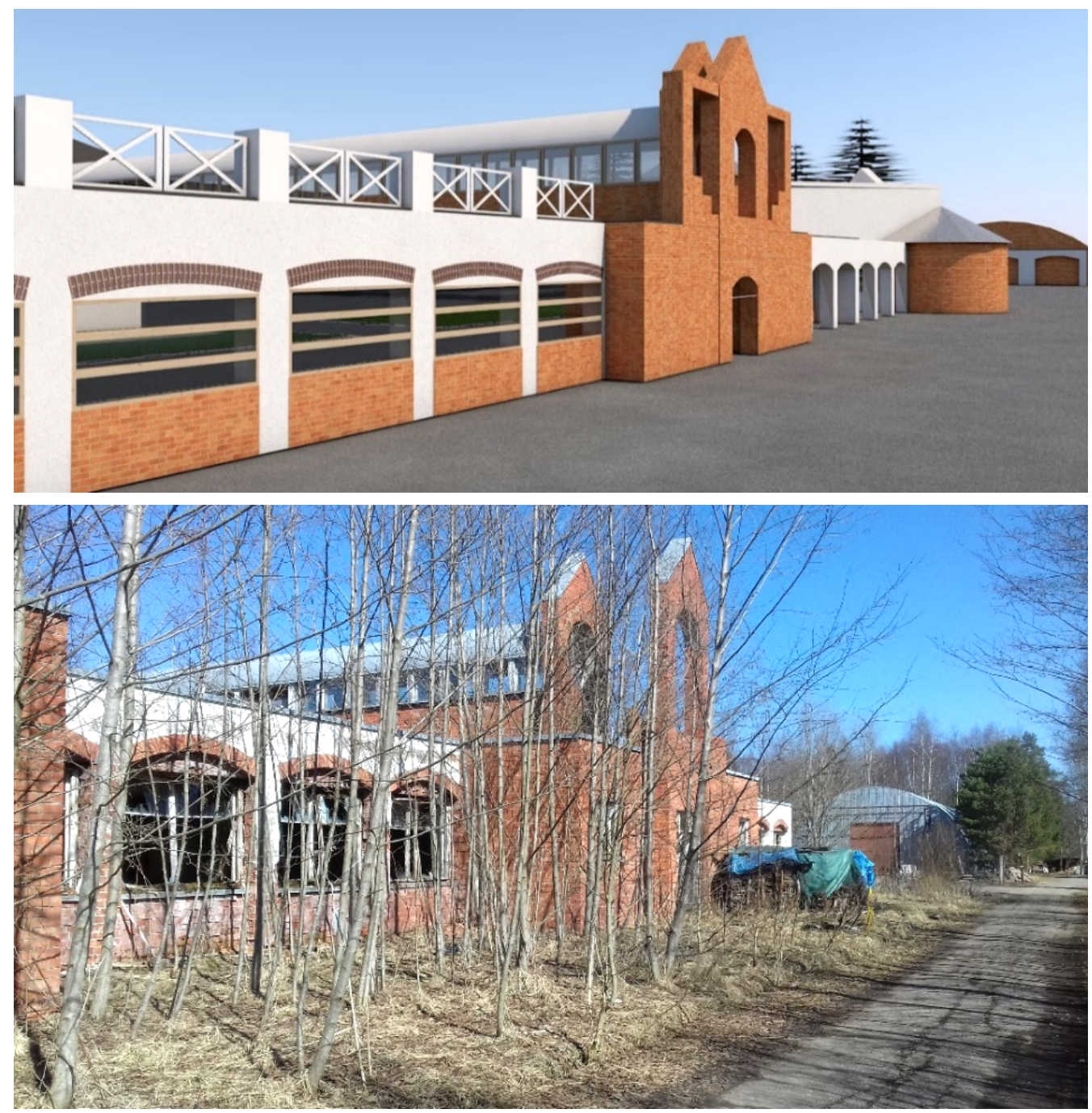

Figs. 3a, b. The designed appearance (a) of the southern façade with the entrance, and (b) how it looks today. (Sources: (a) Oksana Zhukova, (b) Photo: Simon Bell). Note that a curtain wall with railings above was supposed to have been built in front of the arched sections with windows while a large section comprising four cylindrical units of different heights surrounding a cubic element and an imposing doorway was never built - it would have changed the whole appearance and compositional balance if it had been completed. It is difficult nowadays to get a good perspective of the façade due to the degree of overgrown vegetation. 

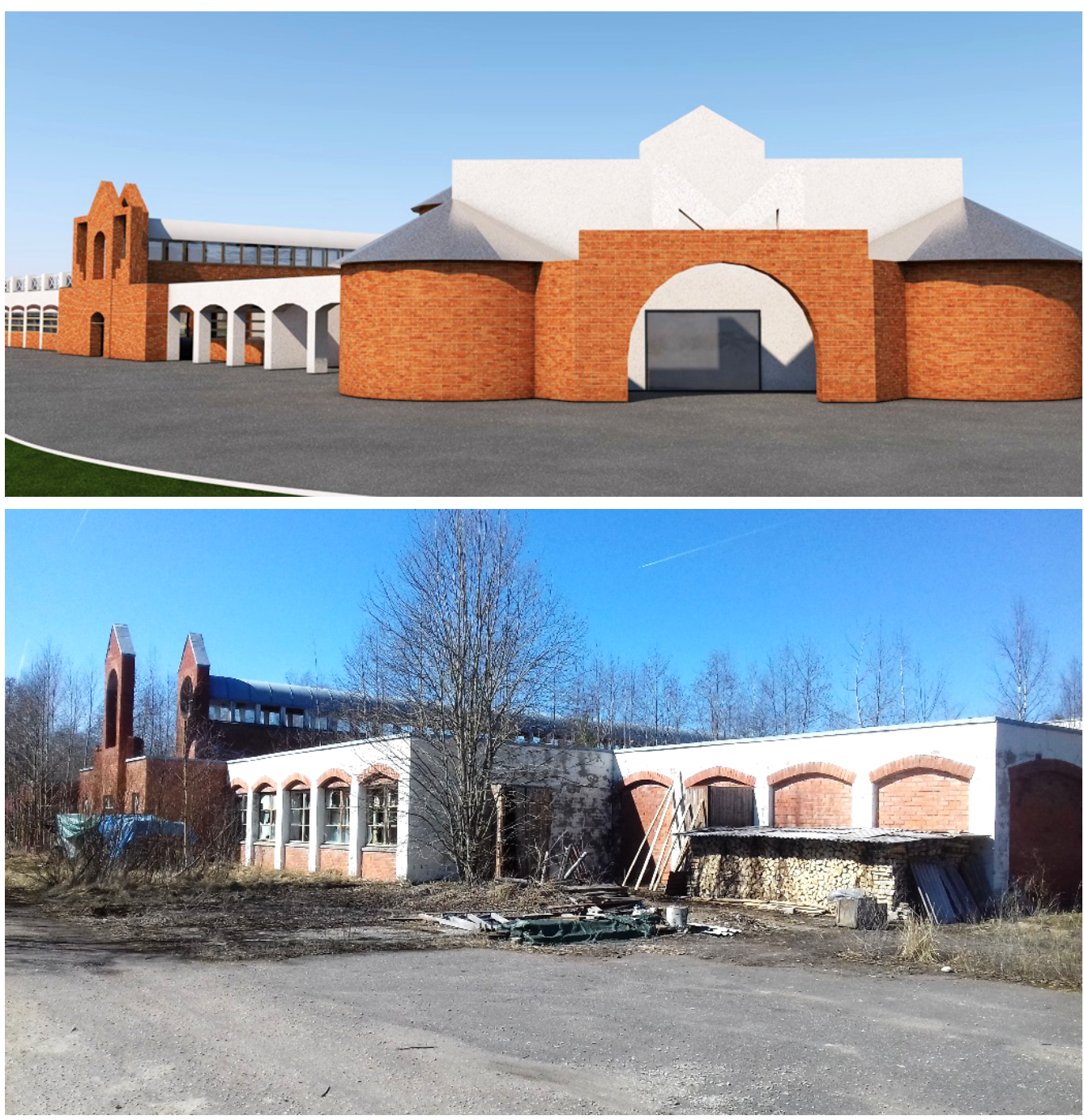

Figs. $4 \mathbf{a}, \mathbf{b}$. The view of the (a) design with the large unbuilt section as it would have appeared, and (b) the appearance as it is today (Sources: (a) Oksana Zhukova, (b) Simon Bell). The arcaded section and the new alternative entrance would have faced the camera.

\section{Laeva}

The Laeva centre consists of a number of krushchevki of two and three stories arranged in a typical open fashion, parallel or at an angle, with spaces in between them together. There are two examples which remain unfinished and some other smaller houses which are abandoned. The layout is very spread out with the school, shop/club, administrative buildings and house of culture some distance away from the residential quarter. The farm building complex is also set some way off and is partly used by a private company. There is also an area of allotment gardens with some summer cottages on them. The landscape is now quite green and the trees break up the views and screen many of the buildings from each other. Originally the landscape would have been much more open and exposed with clear views to all the buildings. 
The original culture house sits at a road junction offering a focal point in the landscape. It is now a ruin but is very distinctive form, comprising cubic volumes at different angles and levels punctuated with regular square windows. It is devoid of any decoration and is an unrelieved grey colour. This is a late addition to the landscape and
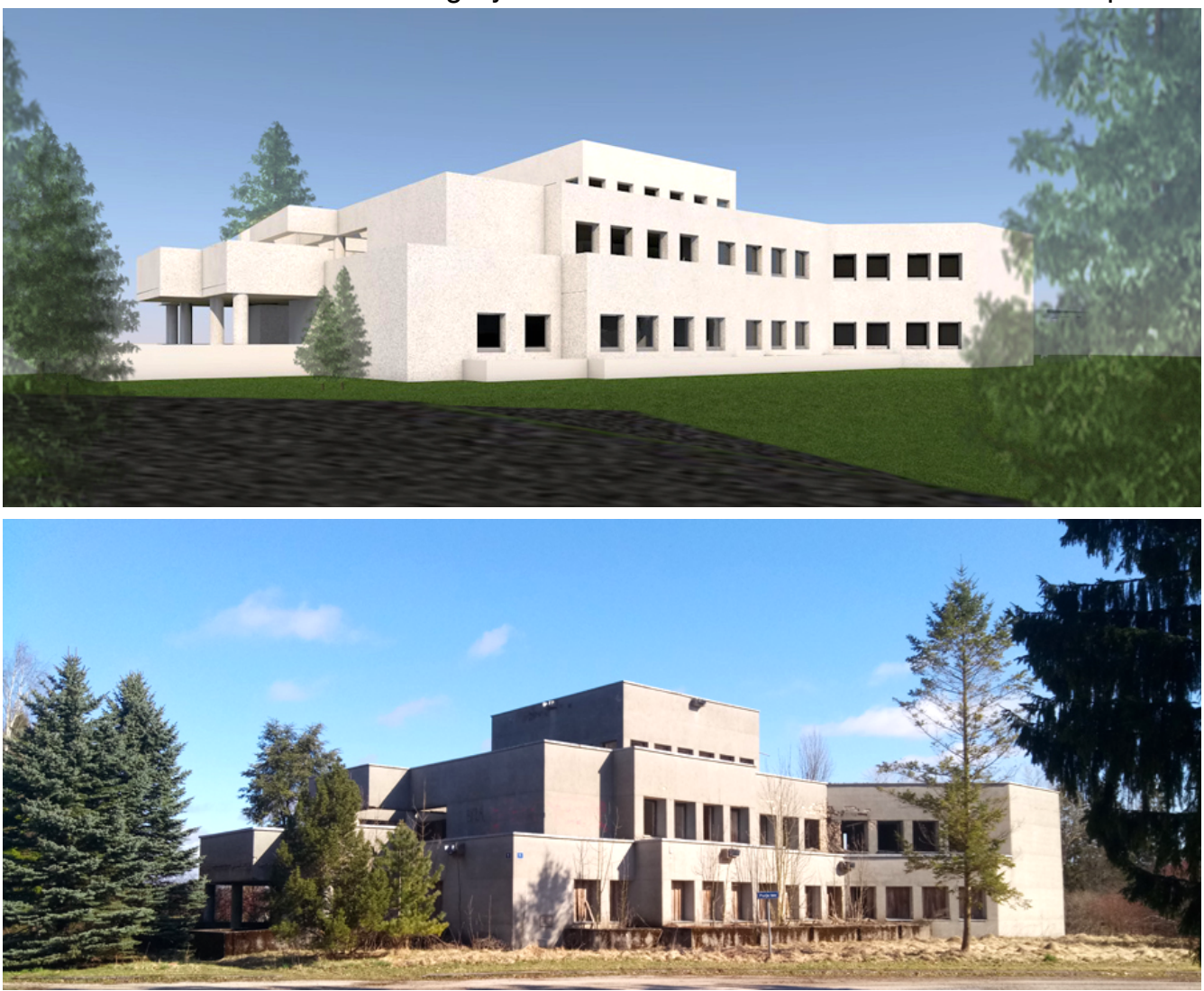

the style contrasts strongly with everything else present.

Figs. 5a, b. The culture or club house designed by Toomas Rein (a) as designed, and (b) as it is now (Sources: Oksana Zhukova).

There is a section not constructed. At a distance, the simplicity of the form and the monochromatic finish looks similar but on closer inspection it is a ruin now. 

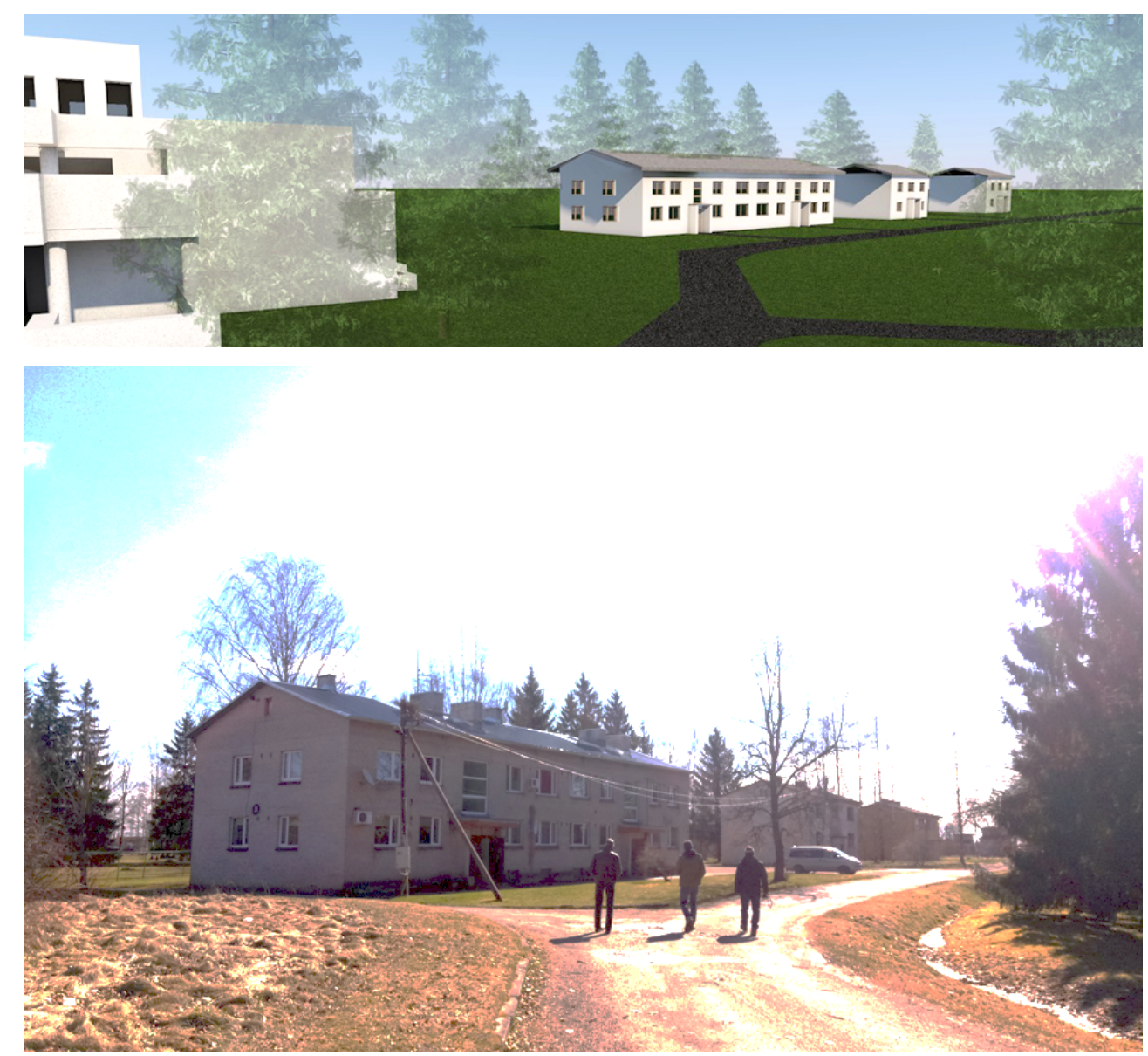

Figs. 6a, b. A view of some two storey krushchevki (a) as originally designed, and (b) as they are now (Source: Oksana Zhukova). The first building is still occupied but the other two (furthest away from the viewpoint) are empty and ruined.

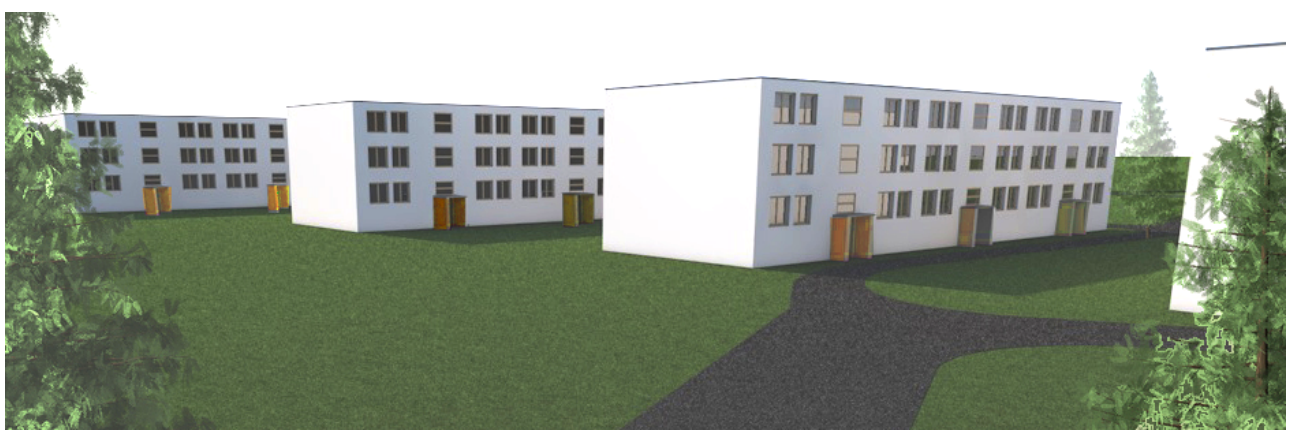

Figure 7: A view of typical three storeys grey panel krushchevki with brick porches. These are all still occupied. Note how urban they appear for a rural setting (source:

Oksana Zhukova).

\section{Discussion and conclusions}

This study enables us to chart the development of the built ensembles of kolkhoz or sovkhoz centres from their initiation to their demise. These rural centres and the 
individual buildings erected there are largely overlooked at the moment although the bespoke buildings offered a role for local Estonian or Latvian architects to test design ideas and explore stylistic aspects of late Modernism or early post-modernism while the standard flats were built according to plan, external landscape features were often omitted. The evolutionary nature of these unique designs is also of interest. However, they were vandalised, robbed of materials and are now abandoned in many cases - an example of a kind of dissonant heritage yet at the same time representing part of the oeuvre of local architects who went on to develop private practices in the post-Soviet era. They represent a lost legacy of the period.

The use of 3D modelling enables us to re-create, at least to some degree, the way in which the settlements must have appeared - or were supposed to appear - in their original form, presenting the ideology and manifestation of the planning and architectural approaches of the 1960s, 1970s and 1980s in relation to the ethos of providing an urban lifestyle in a rural setting.

\section{Acknowledgements}

MODSCAPES is a collaborative research project funded under the HERA - Humanities in the European Research Area 3rd Joint Research Programme dedicated to "Uses of the Past" (20162019). This project has received funding from the European Union's Horizon 2020 research and innovation programme under grant agreement $n^{\circ} 649307$

\section{Short resumes}

Oksana Zhukova MSc is a Ukrainian architect and landscape architect currently a junior researcher at the Estonian University of Life Sciences.

Simon Bell PhD is Chair professor at the Estonian University of Life Sciences and Associate Director of the OPENspace Research Centre at the University of Edinburgh. He has been president of ECLAS, the European Council of Landscape Architecture Schools between 2012 and 2018.

\section{References}

1. BIEWER, L. 2007. "Saksa Riigi Saatkond Tallinnas ja Saksa-Eesti suhted aastatel 1918-1940" [The German Reich's delegation in Tallinn and the German-Estonian relations between 1918 and 1940], in P. Toompere, R. Warfia (eds.), Mälestuskillud. Artiklite kogumik Eesti ja Saksamaa vaheliste diplomaatiliste suhete 85. ja taassõlmimise 15. aastapäevaks [Fragments of Memory. A Collection of Essays on the $85^{\text {th }}$ anniversary of the break and the $15^{\text {th }}$ anniversary of the resumption of diplomatic relations between Estonia and Germany], Berlin, Eesti Vabariigi Suursaatkond Berliinis [Embassy of the Republic of Estonia in Berlin]: 1626. Retrieved from: https://www.estemb.de/static/files/092/malestuskillud.pdf [available on 3 April 2018].

2. ŠTEINS, V. 1986 Lietišķā apdzīvoto vietu ainavu ǵeorāfija [Applied landscape geography of settlement patterns] [in Latvian]. Riga, P. Stučkas Latvijas Valsts Universitāte.

3. BELL, S.; NIKODEMUS, O.; PENEZZE, Z. et al. 2009. "Management of cultural landscapes: what does this mean in the Former Soviet Union: A case study from 
Latvia", Landscape Research, vol. 34, $\mathrm{n}^{\circ} \quad$ 4: 425-455. DOI: https://doi.org/10.1080/01426390903020328

4. KIVIMAA, E. 1976. "Eesti NSV pollumajanduse kollektiviseerimine aastail 19471950" [Collectivisation of Agriculture in the Estonian SSR in the Years of 19471950], in E. Tõnurist (ed.), Sotsialistliku põllumajanduse areng Nõukogude Eestis [Development of the Socialist Agriculture in Soviet Estonia], Tallinn, Valgus: 6993.

5. NIKODEMUS, O.; BELL, S.; GRINE, I. et al. 2005. "Impact of economic, social and political factors on the landscape structure of the Vidzeme Uplands in Latvia", Landscape and Urban Planning, vol. 70, $\mathrm{n}^{\circ}$ 1-2: 57-67.

DOI: https://doi.org/10.1016/j.landurbplan.2003.10.005

6. LŪSE, M.; JĀKOBSONE, A. 1990. "Development of the idea of country villages" (in Russian). Proceedings of the Latvian Academy of Sciences A, $n^{\circ} 7:$ 87-97

7. GRĀVE Z. AND LŪSE M., 1990. "Designing and practice of rural settlement in Latvia" (in Russian), Proceedings of the Latvian Academy of Sciences A, $\mathrm{n}^{\circ}$ 7: 76-85.

8. RIEKSTIN̦Š, J. 2001. From individual farms to socialist villages (in Latvian). The Latvian Herald: 134.

9. PANTELEJEV, V. 1968. "Eesti maa-asulate uus ilme" [New Look of the Estonian Rural Settlements], Ehitus ja arhitektuur, n`3: 3-6.

10. JÄÄTS, I. 2004. "Sotsialistlik pollumajandus: varane kolhoosiaeg Oisu piirkonnas Jarvamaal I" [Socialist Agriculture: Early Kolkhoz Time in the Area of Oisu in Jarva County - part I], Akadeemia 1: 132-168. Retrieved from: https://www.digar.ee/viewer/et/nlib-digar:104067/161879/page/71 [available on 29 January 2019].

11. VIIRMA, V. 1983. "Keskusehooned ja klubid ainuprojektide jargi" [The Central Buildings and Clubs by the Original Design], Sotsialistlik põllumajandus, $\mathrm{n}^{\circ} 22: 28-30$.

12. MURULA, R. (ed.) 2009. Linnaehituslik analüüs ja planeerimisettepanekud 1960ndate tüüpelamute (seeria 1-317) kvartalite kaasajastamiseks [Urban analysis and planning proposals for 1960s typical buildings (series 1-317)]. [Research report for Tallinna Linnaplannerismise Amet (Tallinn City Planning Agency)]. Tallinn, Tallinna Tehnikakõrgkooli - Arhitektuuri instituut [TTK University of Applied Sciences Institute of Architecture]. Retrieved from: http://murula.eu/failid/visioon/l_linnaehituslik_analyys.pdf [available on 29 January 2019].

13. KURG, A. 2009. "Architects of the Tallinn School and the critique of Soviet modernism in Estonia", The Journal of Architecture, vol. 14, $\mathrm{n}^{\circ}$ 1: 85-108. DOI: https://doi.org/10.1080/13602360802705171

14. INGERPUU, L. 2018. "Socialist architecture as today's dissonant heritage: administrative buildings of collective farms in Estonia", International Journal of Heritage Studies, vol. 24, $\mathrm{n}^{\circ} \quad 9, \quad 954-968$. DOI: https://doi.org/10.1080/13527258.2018.1428664

15. PAULUS, K. 2013. Ado Eigi, Tallinn, Solnessi Arhitektuurikirjastus.

16. KARU, M. 2012. Laeva katsesovhoosi keskuse dokumenteerimine [Documentation of the experimental state farm at Laeva]. Tallinn, Estonian Academy of Arts EKA Muinsuskaitse- ja restaureerimise osakond. Tallinn. 